DOI :

\begin{tabular}{l|lll|l}
\hline History Article & Received: February 2020 & Approved: February 2020 & Published: February 2020 & \\
\hline
\end{tabular}

\title{
PEMBERIAN NUTRISI AB MIX PADA LIMBAH AIR KOLAM DENGAN MENGGUNAKAN SISTEM HIDROPONIK BERPOTENSI MENINGKATKAN PERTUMBUHAN TANAMAN SAWI (Brassica juncea L)
}

\author{
Amirul Mukminin $^{1}$ Agus Sutanto $^{2}$ Muhfahroyin $^{3}$ \\ ${ }^{123}$ Magister Pendidikan Biologi, Program Pascasarjana, Universitas Muhammadiyah Metro \\ E-mail: Amirulmukminin825@gmail.com ${ }^{1}$, sutanto11@gmail.com ${ }^{2}$, muhfahroyin@yahoo.com ${ }^{3}$
}

\begin{abstract}
Abstrak: Kotoran ikan yang sering menimbulkan masalah karena bau yang tidak sedap dan membuat kolom menjadi kotor ternyata dapat memberikan manfaat, Sisa pakan yang ditebar di kolam yang tidak dimakan ikan dan mengendap di dalam kolam juga dapat bermanfaat, baik limbah yang berasal dari budidaya di kolam ikan dapat dimanfaatkan untuk hidroponik Air limbah air tambak ikan mengandung nitrogen dan fosfor yang berasal dari feses, sisa makanan dan urine ikan yang memiliki kandungan protein tinggi Nitrogen dan fosfor sangat dibutuhkan oleh pertumbuhan tanaman baik sayuran maupun tanaman lainnya. Untuk mengetahui apakah limbah tambak ikan dapat bermanfaat bagi pertumbuhan tanaman maka perlu dilakukan penelitian tentang pengaruh limbah tambak ikan terhadap pertumbuhan tanaman. Tujuan dari penelitian ini adalah untuk mengetahui pengaruh limbah tambak ikan terhadap pertumbuhan tanaman. tanaman sayur. Penelitian ini mengelompokkan perlakuan menjadi dua kelompok. Kelompok pertama adalah kelompok perlakuan yang memberikan nutrisi campuran $\mathrm{AB}$ pada limbah cair lele dan limbah ikan gurami.
\end{abstract}

Kata Kunci: hidroponik, limbah air kolam, tanaman sayur

\begin{abstract}
Fish droppings that often cause problems due to unpleasant odors and making the column dirty can actually provide benefits. Remaining feed stocked in ponds that are not eaten by fish and settling in the pond can also be beneficial.Both of the waste originating from the cultivation in the fish pond can be utilized for hydroponics. Catfish pond water wastewater contains nitrogen and phosphorus derived from feces, leftover food and urine of fish that have high protein content.Nitrogen and phosphorus are needed by plant growth both vegetables and other plants. To find out whether fish pond waste can be beneficial for plant growth, it is necessary to conduct a research on the influence of fish pond waste on plant growth.The purpose of this study was to determine the effect of fish pond waste on the growth of vegetable plants.This study grouped the treatment into two groups. The first group is the treatment group giving AB mix nutrition in catfish wastewater and gouramy wastewater.
\end{abstract}

Keywords: hydroponics, pond waste water, vegetable crops

\section{How to Cite}

Mukminin, Amirul, Agus Sutanto. Muhfahroyin. 2020. Pemberian Nutrisi AB Mix pada Limbah Air Kolam dengan Menggunakan Sistem Hidroponik Berpotensi Meningkatkan Pertumbuhan Tanaman Sawi (brassica juncea 1). Biolova 1(1). 39-44. 
Kotoran ikan yang banyak menimbulkan masalah yaitu bau yang tidak sedap dan dapat membuat kolam menjadi kotor ternyata bisa memberikan manfaat bagi tumbuhan. Pakan yang ditebar di kolam yang tidak termakan oleh ikan dan mengendap di bawah kolam pun bisa bermanfaat pula. Kedua limbah yang berasal dari hasil budidaya di kolam ikan tersebut dapat dimanfaatkan sebagai pupuk untuk tanaman terkhusus tanaman Hidroponik.

Kegiatan budidaya ikan lele akan menghasilkan limbah yang berasal dari kotoran sisa pakan atau feses, sisa pakan ikan memiliki kandungan protein tinggi. Protein tersebut diuraikan menjadi polipeptida, asamamino, dan amonia sebagai produk akhir. Semua ini tidak baik untuk pertumbuhan ikan itu sendiri tetapi bagus untuk pertumbuhan tanaman. Di dalam air amonia terdapat dalam 2 bentuk, yaitu $\mathrm{NH}_{4}^{+}$atau biasa disebut Ionized Ammonia (IA), yang kurang beracun dan $\mathrm{NH}_{3}$ atau Unionized Ammonia (UIA) yang beracun (Colt dan Amstrong,1981 dalam Kordi, 2012).

Pergantian air secara terperiode atau secara terjadwal merupakan salah satu cara yang biasa dilakukan oleh pembudidaya ikan lele untuk mengatasi air limbah kolam agar tidak berbahaya kepada ikannya. Cara demikian tidaklah terlalu efektif karena membutuhkan air dalam jumlah besar untuk proses budidaya itu sendiri sehingga hal tersebut akan menjadi masalah saat musim kemarau atau pada daerah yang memiliki sumber daya air yang terbatas, sedangkan air limbah kolam yang dibuang tanpa melalui pengolahan terlebih dahulu sangat berbahaya dan berpotensi untuk mencemari lingkungan perairan dan mengakibatkan air yang ada di lingkungan tersebut menjadi tercemar.
Air kolam yang sudah kotor dan sudah tidak layak untuk digunakan biasanya diganti dengan yang baru dan yang kotor akan dibuang begitu saja karena air kolam yang kotor itu dianggap limbah dan tidak bermanfaat bagi masyarakat pembudidaya. Seiring perkembangan teknologi pertanian, ternyata bekas air kolam ikan yang kotor itu bisa dimanfaatkan untuk menyiram tanaman karena banyak mengandung unsur hara seperti Nitrogen dan Phosfor yang dibutuhkan tanaman.

Protein dan urea merupakan sumber utama nitrogen dalam limbah ini yang secara keseluruhan atau sebagiannya terdiri atas sejumlah besar amino, karbon, hidrogen, sulfur dan fosfor (Wheaton, 1977 dalam Sumoharjo, 2010).

Limbah air pada kolam gurame dapat juga dimanfaatkan untuk pupuk organik cair setelah dicampur dengan baktri EM-4. Hal ini dikarenakan limbah pada air kolam gurame banyak mengandung zat-zat yang dapat membantu proses pertumbuhan tanaman. Penambahan EM-4 digunakan untuk menguraikan limbah secara biologis yakni dengancara fermentasi. Fermentasi tersebut dimaksudkan memberikan kesempatan untuk mikroorganisme efektif agar aktif dan berkembangbiak lebih banyak sehingga dapat bekerja dengan efisien dan optimal dalam proses penguraian limbah itu sendiri. Sehingga limbah air kolam gurame dapat dijadikan sebagai pupuk organik cair dan menyuburkan tanaman.

Tanaman sayur adalah salah satu tanaman yang terdapat di Negara Indonesia. Banyak sekali petani Indonesia yang membudidayakan berbagai jenis tanaman sayuransayuran. Hal tersebut disebabkan karena iklim di Indonesia sangat mendukung serta memungkinkan 
untukperkembangan tanaman sayursayuran yang banyak jenisnya, baik sayur dataran rendah hingga sayur dataran tinggi. Sehingga jika ditinjau dari aspek klimatologis Indonesia sangat tepat untuk dikembangkan untuk bisnis sayuran.

Berdasarkan hal tersebut, maka perlu adanya inovasi baru guna untuk memanfaatkan air limbah kolam sebagai pupuk tanaman supaya tidak menjadi limbah dan mencemari lingkungan.Tujuan dari penulisan artikel ini adalah untuk mengetahui pemberian Nutrisi AB Mix pada limbah air kolam dapat meningkatkan pertumbuhan tanaman sawi (Brassia juncea $\mathrm{L}$ ) dengan menggunakan sistem hidroponik.

\section{METODE}

Metode yang digunakan dalam artikel ini adalah studi dokumentasi mengkaji beberapa artikel yang berhubungan dengan pemberian Nutrisi AB Mix pada limbah air kolam.

\section{HASIL KAJIAN DAN PEMBAHASAN}

\section{Tanaman Sawi (Brassia juncea L)}

Tanaman sawi memiliki kandungan berupa protein, lemak, karbohidrat, $\mathrm{Ca}, \mathrm{P}, \mathrm{Fe}$, Vitamin A, Vitamin B, dan Vitamin C, serta ada beberapa jenis tanaman sawi yang perlu kita ketahui. Secara umum tanaman sawi mempunyai daun panjang, halus, tidak berbulu, dan tidak berkrop. Petani kita hanya mengenal 3 macam sawi yang biasa dibudidayakan yaitu: sawi putih (sawi jabung), sawi hijau, dan sawi huma.

Sawi baik digunakan untuk Ibu Hamil, khasiat sawi yang sangat luar biasa, mampu menangkal hipertensi, penyakit jantung, dan berbagai jenis kanker. Konsumsi sayur-sayuran sudah menjadi kebutuhan primer karena kandungan gizinya yang sangat tinggi dan baik buat kesehatan. Menurut Iswati (2011), tanaman sawi (Brassica juncea L) merupakan jenis tanaman semak, memiliki tinggi $\pm 50 \mathrm{~cm}$, batang tegak, masif, licin, berwarna hijau. Memiliki daun tunggal, bentuk lonjong, tepi rata sampai bergerigi, ujung tumpul, pangkal meruncing, warna hijau, bunga majemuk terdapat di ujung batang, kelopak halus, warna hijau, kekuningan, mahkota berwarna kuning, buah polong. Sifat khas menghangatkan. Tanaman sawi ini juga mengandung minyak atsiri dan glikosida yang terdapat pada biji minyak lemaknya, serta memiliki khasiat anti inflamasi. Selain itu tanaman sawi juga memiliki kandungan vitamin $\mathrm{K}, \mathrm{A}, \mathrm{C}, \mathrm{E}$ dan asam folat tergolong sangat tinggi.

Produksi pada tanaman sawi terus mengalami penurunan. Penurunan produksi dikarenakan salah satunya teknik budidaya yang diterapkan oleh petani tersebut sehingga tidak maksimal hasil yang diperolehnya (Asikin, 2013). Tanaman sawi sangat membutuhkan nutrisi-nutrisi yang diperlukan seperti Nitrogen dan Phosfor. Kedua unsur hari ini sangat dibutuhkan untuk proses pertumbuhan tanaman. Dalam pemberian nutrisi harus teratur dan seimbang sehingga tanaman sawi tumbuh dengan maksimal.

\section{Nutrisi AB Mix}

Nutrisi AB Mix ini merupakan pupuk khusus yang digunakan untuk budidaya hidroponik, komposisi unsur hara dalam pupuk telah disesuaikan dengan kebutuhan tanaman tersebut. Pupuk ini terdiri dari dua komponen yaitu pupuk A dan pupuk B. Satu paket pupuk hidroponik AB mix mengandung 12 unsur bahan kimia. Dari kedua komponen A dan B memiliki unsur yang berbeda-beda. Menurut Tonny (2011), Dalam pupuk 
A terdapat 3 unsur, yaitu Calsiumamonium-nitrat, Kalium-nitrat dan $\mathrm{Fe}$ EDTA. Sedangkan dalam pupuk B terdapat 10 unsur, yaitu Kalium-dihidro-fosfat, Kalium-nitrat, Ammonium-sulfat, Kalium-sulfat, Magnesium-sulfat, Mangan-sulfat, Tembaga (Kupro)-sulfat, Seng-sulfat, Asam borat atau Boraks, Amoniumhepta-molibdat atau Natrium-heptamolibdat. Sehingga dari kedua komponen tersebut memiliki unsur yang berbeda dan pada pupuk B memiliki lebih banyak unsur dari pada pupuk A. Pupuk A dan pupuk B tidak dapat dicampur menjadi satu harus dipisah terlebih dahulu dalam pelarutannya karena bila kation kalsium $\left(\mathrm{Ca}^{2+}\right)$ dalam pekatan $\mathrm{A}$ bertemu dengan anion sulfat $\left(\mathrm{SO}^{4-}\right)$ dalam pekatan $\mathrm{B}$ akan terjadi endapan kalsium sulfat $\left(\mathrm{CaSO}_{4}\right)$ sehingga unsur $\mathrm{Ca}^{2+}$ dan $\mathrm{S}$ tidak dapat diserap oleh akar tanaman dan menunjukkan gejala defisiensi Ca dan S.

Menurut Rakhman, dkk (2015), Media pupuk AB mix itu lebih efektif dibandingkan nutrisi dari air limbah ikan (ikan komet dan ikan nila). Indikatornya adalah tingggi tanaman, jumlah helai daun, panjang akar, dan berat tanaman. Cara pembuatan larutan nutrisi AB Mix dengan cara melarutkan AB mix A (83 gram) dan AB mix B (83 gram) masing-masing ke dalam $500 \mathrm{ml}$ air, kedua larutan tersebut dicampurkan ke dalam $100 \mathrm{~L}$ air kemudian diaduk hingga tercampur rata, nutrisi ini disimpan dalam ember plastik. Larutan ini dapat digunakan semau kita selama kandungan dari pupuk tersebut masih ada, dan sesuai ukuran yang sudah ditentukan.

\section{Limbah Air Kolam}

Limbah air kolam seringkali menimbulkan suatu masalah karena bau yang muncul tidak sedap dan membuat kolom menjadi kotor. Sisa pakan yang ditebar di kolam yang tidak termakan oleh ikan dan mengendap di kolam bisa bermanfaat untuk pertumbuhan tanaman, karena dari kotoran tersebut banyak mengandung unsur hara nitrogen dan phosfor yang dibutuhkan oleh tanaman. Dalam limbah air kolam mempunyai kandungan amoniak yang besar yang dapat berpengaruh dalam budidaya, mengingat amoniak dalam perairan besifat toksik dan bahkan bisa mematikan ikan. Organisme akuatik umumnya membutuhkan protein yang cukup tinggi dalam makanannya. Adapun demikian organisme akuatik hanya dapat meretensi protein sekitar 20-25 dan selebihnya akan terakumulasi dalam air.

Menurut Siregar (2010), Karakter atau sifat air limbah berbeda-beda yaitu senyawa organik dan senyawa anorganik. Senyawa organik merupakan karbon yang dikombinasi dengan satu atau lebih elemen-elemen lain $(\mathrm{O}, \mathrm{N}, \mathrm{P}, \mathrm{H})$ saat ini terdapat lebih dari dua juta jenis senyawa organik yang telah diketahui. Semua unsurunsur yang terkandung di dalam limbah air kolam sangat bermanfaat untuk proses pertumbuhan tanaman terutama nitrogen dan phosfor. Menurut Hidayah (2011), Pengolahan pada air limbah yang mengandung bahan organik, secara biologis dapat dilakukan dengan beberapa jenis cara pengolahan, yaitu yang pertama aerobik, anaerobik. Proses pengolahan air limbah secara biologis tersebut, mempunyai beberapa kelebihan dan kekurangannya. Untuk itu diperlukan upaya dengan teknologi yang sederhana, murah, mudah, tepat guna, ekonomis serta operasional dan pemeliharannya yang tidak memerlukan tenaga yang khusus.

Banyak para petani ikan tidak tahu manfaat dari air limbah kolam itu sendiri. Masalah air limbah di Indonesia ini sampai saat ini masih menjadi sebuah masalah yang serius, 
dalam pengolahan air limbah tidak maksimal. Dengan berkembangnya zaman terdapat teknologi yang digunakan untuk mengatasi masalah limbah air ini, aktivitas mikroorganisme sangat penting dalam menguraikan senyawa yang ada pada limbah air kolam, sehingga limbah tersebut dapat digunakan dan dimanfaatkan kembali.

Menurut Maharani (2016), Pembuangan limbah air kolam ikan di lingkungan sekitar kolam yang akan dilakukan terus menerus dapat berdampak tidak baik atau negatif bagi masyarakat sekitar, terutama terjadinya pencemaran air sumur. Oleh karena itu, pengolahan limbah kolam ikan menjadi hal penting untuk dilakukan sebelum limbah tersebut dibuang ke lingkungan. Salah satunya memanfaatkan air limbah kolam tersebut sebagai pupuk untuk pertumbuhan tanaman, dengan adanya air limbah tersebut dapat membantu para petani sayuran untuk memberikan unsur hara pada tanamannya, sehingga membantu proses pertumbuhan tanaman serta air limbah tersebut tidak terbuang sia-sia.

\section{KESIMPULAN}

Satu paket pupuk hidroponik $A B$ mix mengandung 12 unsur bahan kimia. Dalam pupuk A terdapat 3 unsur, yaitu Calsium-amonium-nitrat, Kalium-nitrat dan Fe-EDTA. Sedangkan dalam pupuk B terdapat 10 unsur, yaitu Kalium-di-hidro-fosfat, Kalium-nitrat, Ammonium-sulfat, Kalium-sulfat, Magnesium-sulfat, Mangan-sulfat, Tembaga (Kupro)sulfat, Seng-sulfat, Asam borat atau Boraks, Amonium-hepta-molibdat atau Natrium-hepta-molibdat.

Sifat air limbah kolam berbedabeda yaitu senyawa organik dan senyawa anorganik. Senyawa organik merupakan karbon yang dikombinasi dengan satu atau lebih elemen-elemen lain $(\mathrm{O}, \mathrm{N}, \mathrm{P}, \mathrm{H})$, serta banyak mengandung unsur Nitrogen dan Phosfor dimana unsur ini dapat membantu proses pertumbuhan tanaman.

\section{SARAN}

Penelitian mengenai pemberian nutrisi AB Mix pada limbah air kolam agar dilakukan lebih mendalam mengenai perannya untuk pertumbuhan tanaman sayur.

\section{DAFTAR RUJUKAN}

Asikin, Zaenal; Wijaya; Siti Wahyuni. 2013. Pengaruh Takaran Pupuk Nitrogen dan Pupuk Organik Kascing Terhadap Pertumbuhan dan Hasil Tanaman Caisim (Brassica juncea L.) Kultivar Tosakan. Jurnal Agrijati. Vol.24 No. 1 Desember 2013. Alumni Fakultas Pertanian: Dosen Fakultas Pertanian.

Hidayah, Euis N; Wahyu Aditya. 2011. Potensi dan Pengaruh Tanaman pada Pengolahan Air Limbah Domestik dengan Sistem Constructed Werland. Jurnal Ilmiah Teknik Lingkungan. Vol. 2 No. 2. Jawa Timur: Universitas Pembangunan Nasional.

Iswati, Evelina; Anton Kharisma. 2011. Tanaman Kesehatan. Jakarta: Sumber Citra Lestari.

Maharani, Nur A; Pinjung Nawang Sari. 2016. Penerapan Aquaponic sebagai Teknologi Tepat Guna Pengolahan Limbah Cair Kolam Ikan. Indonesian Journal of Community Engagement. Vol. 01, No. 02. Maret 2016. UGM: Fakultas Biologi dan Pertanian. 
Rakhman, Aulia; Budianto Lanya;

R.A. Bustomi Rosadi; M. Zen

Kadir. 2015. Pertumbuhan

Tanaman Sawi dengan

Menggunakan Sistem

Hidroponik dan Aquaponik.

Jurnal Teknik Pertanian

Lampung. Vol. 04, No. 04.

Fakultas Pertanian: UNILA. 